\title{
EFEKTIVITAS KEBIJAKAN PENYALURAN LOGISTIK BENCANA
}

\author{
Martinus Syamsudin \\ Fakultas Ilmu Sosial dan Ilmu Politik Universitas Kapuas \\ Email: syamsudinmartinus@yahoo.co.id \\ Universitas Kapuas Sintang, Jln. Oevang Oeray No. 92 Sintang Kalimantan Barat
}

\begin{abstract}
Abstrak: Penelitian ini adalah Efektifitas Kebijakan Penyaluran Logistik Bencana Kabupaten Sintang tujuan yang ingin dicapai menganalisis dan teridentifikasinya Efektifitas Kebijakan Penyaluran Logistik Bencana Kabupaten Sintang. Metode penelitian ini menggunakan penelitian Deskriptif kualitatif. Hasil penelitian ini menunjukan Mekanisme Penyaluran Bantuan yang dilakukan sesuai prosedur yang dilakukan yakni SOP penanganan bencana. Bentuk Bantuan yang disalurkan sudah sesuai dengan butuhan masyarakat yang terdampak banjir yakni kebutuhan pokok, obat-obatan dan pembinaan sosial bagi korban. Efektivitas penyaluran bantuan telah dilakukan sehingga butuhan dan tujuan logistik dapat terpantau serta ada penilaian terhadap penyimpangan-penyimpangan dalam pelaksanaan pendistribusi logistik.
\end{abstract}

Kata Kunci : Efektifitas KEbijakan

\section{Latar Belakang Penelitian}

Badan Penanggulangan Bencana Daerah (BPBD) Kabupaten Sintang dibentuk berdasarkan Peraturan Daerah Kabupaten Sintang Nomor 1 Tahun 2011 Tentang Perubahan Atas Peraturan Daerah Kabupaten Sintang Nomor 21 Tahun 2008 Tentang Pembentuk Organisasi Perangkat Daerah Kabupaten Sintang. Berdasarkan peraturan tersebut Badan Penanggulangan Bencana Daerah Kabupaten Sintang mempunyai fungsi: 1) merumuskan dan menetapkan kebijakan penanggulangan bencana daerah dan penanganan pengungsian dengan bertindak cepat, efektif dan efisien. 2) Mengkoordinasikan pelaksanaan kegiatan penanggulangan bencana daerah secara terencana, terpadu dan menyeluruh.

BPBD adalah lembaga pemerintah nondepartemen yang melaksanakan tugas penanggulangan bencana di daerah baik Provinsi maupun Kabupaten/Kota dengan berpedoman pada kebijakan yang ditetapkan oleh Badan Koordinasi Nasional. Berdasarkan Peraturan Kepala Badan Nasional Penanggulangan Bencana Nomor 1 Tahun 2008 Tentang Organisasi Dan Tata Kerja Badan Penanggulangan Bencana Daerah (BPBD) mempunyai tugas: Memberikan pedoman dan pengarahan terhadap usaha penanggulangan bencana yang mencakup pencegahan bencana, penanganan tanggap darurat, rehabilitasi, dan rekonstruksi secara adil dan setara; Menetapkan standardisasi dan kebutuhan penyelenggaraan penanggulangan bencana berdasarkan peraturan perundang undangan; Menyampaikan informasi kegiatan penanggulangan bencana kepada masyarakat.
BPBDmenyelenggarakan fungsi: Perumusan dan penetapan kebijakan penanggulangan bencana dan penanganan pengungsi dengan bertindak cepat dan tepat serta efektif dan efisien; dan Pengkoordinasian pelaksanaan kegiatan penanggulangan bencana secara terencana, terpadu, dan menyeluruh. Peraturan Daerah Sintang Nomor 1 Tahun 2011 pada pasal 1 ayat (9) dinyatakan bahwa bencana adalah peristiwa atau rangkaian peristiwa yang mengancam dan mengganggu kehidupan dan penghidupan masyarakat yang disebabkan baik oleh faktor alam dan atau faktor non alam maupun faktor manusia, sehingga mengakibatkan timbulnya korban jiwa manusia, kerusakan lingkungan, kerugian harta benda dan dampak psikologis.

Bencana bajir dan kebakaran lahan, masyarakat mengalami banyak kerugian, terutama kerugian pihak, baik warga yang menempati wilayah-wilayah banjir sampai di Pedesaan (Wilayah Sawah dan peternakan, serta ladangladang) akan tetapi yang mengalami kebakaran lahan tak sedikit juga masyarakat yang mengalami kebakaran kebun karet yang merupakan sumber penghasilan ekonomi bagi masyarakat. Hal ini merupakan bukan kali pertama terjadi, masyarakat berargumen bahwa penyebab utama terjadinya banjir karena banyak wilayah hutan di buka menjadi lahan perkebunan sawit,sehingga hilangnya beberapa tempat penyerapan air, yang tidak di imbangi dengan perbaikan kondisi lingkungan. Tak dapat di pungkiri bahwa curah hujan yang tinggi juga merupakan faktor utama kondisi ini, efek dari cuaca yang susah untuk di prediksi, merupakan efek dari pemanasan global (Global Warming), 
Kondisi yang terjadi pada kondisi diatas adalah cerminan dari sebuah kebijakan yang tidak berdasar kepada Kajian Lingkungan Hidup Strategis (KLHS), Banjir yang terjadi hampir setiap tahun (bukan hanya di daerah perkotaan, melainkan daerah-daerah yang Sudah menjadi langganan Banjir) seharusnya menjadi pelajaran kepada kita sehingga kita dapat membuat sebuah kebijakan yang sifat preventif (pencegahan) untuk meminimalisir Musibah.

Pembelajaran yang sangat berarti bagi semuanya, bahwa apa yang ada dan terjadi saat ini adalah ulah kita sendiri, dan sudah sepatutnya menjadi pedoman kita kedepan agar mampu melihat dengan bijak pembangunan masa akan datang yang harus sinergi dengan Kajian Lingkungan Hidup Strategis, Kejadian ini mungkin teguran dan himbauan agar setiap manusia bisa lebih bijak dalam mempergunakan dan menjaga alam.

Sudah sepatutnya masyarakat dan seluruh stakeholder khususnya BPBD sudah mengambil langkah untuk meminimalisir dampak dari terjadinya musibah ini. Dari tahun ketahun wilayah tertentu Kabupaten Sintang bisa dikatakan langganan banjir, artinya kita sudah mempunyai gambaran untuk mengambil langkah antisipasi. Namun yang terjadi bencana banjir setiap tahunnya mengejutkan seluruh warga. Padahal BPBD Kabupaten/kota yang mempunyai kontijensi bencana dianggap telah tanggap dalam menghadapi bencana. Tanggap dalam arti mampu membaca situasi misalnya dengan mendirikan posko siaga bencana. Berdirinya posko siaga bencana, BPBD dapat melibatkan seluruh instansi serta menaungi / menahkodai instansi - instansi yang turut andil dalam penanggulangan bencana seperti SAR, TNI, POLRI, Pemerintah Desa dan lain-lain. Sehingga manajemen penanggulangan bencana dapat berjalan dengan lancar karena adanya koordinasi yang baik.

Penanggulangan bencana dilapangan masyarakat yang terkena dampak seperti kebakaran dan banjir yang mencapai ketinggi air hingga 2 meter merendam memukiman, membuat perekonomian masyarakat lumpuh total. Dengan keadaan itu masyarakat sangat membutuhan bantuan makan, minuman dan pakaian, akan tetapi hal tersebut tidak meraka dapatkan. Padahal dengan kondisi masyarakat yang darurat demikian merupakan tanggungjawab pemerintah terutama dalam bidang tanggap bencana.

Penelitian ini bertujuan untuk dapat menganalisis dan terdeskripsikannya,Penyaluran Logistik Bencana Kabupaten Sintang. Adapun manfaat dari penelitian ini adalah antara lain sebagai berikut; (1) Secara Teoritis, salah satu karya ilmiah yang dapat menambah kontribusi akademis dibidang Ilmu Administrasi Publik yang berkenaan dengan Kebijakan Publik. (2) Secara Praktis diharapkan dapat memberi kontribusi dan dasar pemikiran Program Penyaluran Bantuan Bencana Badan Penanggulangan Bencana Daerah.

\section{Kajian Teori}

Menurut Grindle (dalam wahab 2002:127) menyebutkan "proses implementasi kebijakan yang efektif hanya dapat dimulai apabila:a). Tujuantujuan dan Saran-saran yang semula bersifat umum telah diperinci. b). Program-program aksi telah dirancang dan c). Sejumlah dana atau biaya telah dialokasikan untuk mewujudkan tujuan-tujuan dan sasaran tersebut, tanpa adanya syarat-syarat tersebut, maka kebijakan negara boleh dikatakan sekedar retorika atau slogan politik belaka".

Untuk mengetahui keberhasilan dari kebijakan negara, maka kebijakan negara itu perlu diimplementasikan. Menurut Meter dan Horn (dalam Wibawa, 2005:14) mendefinisikan bahwa: Implementasi kebijakan sebagai tindakan yang dilakukan oleh publik atau swasta baik secara individu maupun kelompok yang ditujukan untuk mencapai tujuan yang telah ditetapkan dalam keputusan kebijakan. Definisi tersebut menyiratkan adanya upaya mentransformasikan keputusan kedalam kegiatan operasional, serta mencapai perubahan seperti yang dirumuskan oleh keputusan kebijakan.

Menurut Widjaya (1993:32) mengemukakan: "Efektivitas adalah hasil membuat keputusan yang mengarahkan melakukan sesuatu dengan benar, yang membantu memenuhi misi suatu perusahaan atau pencapaian tujuan". Selanjutnya Permata Wesha (1992:148) mengatakan: Efektivitas adalah keadaan atau kemampuan berhasilnya suatu kerja yang dilakukan oleh manusia untuk membrikan guna yang diharapakan untuk melihat efektivitas kerja pada umumnya dipakai empat macam pertimbangan yaitu : Pertimbangan ekonomi, Pertimbangan fisiologi, Pertimbangan Psikologi dan Pertimbangan Sosial".

Sarwoto (1990:126) mengistilahkan efektivitas dengan "berhasil guna" yaitu pelayanan yang baik corak dan mutunya benar-benar sesuai kebutuhan dalam pencapaian tujuan organisasi.

Menurut Campel yang dikutip Ricard M, Steers (1998:45) untuk mengukur efektivitas kerja ada beberapa variable yang biasa dipergunakan 
yaitu: Kesiagaan: Penilaian menyeluruh sehubungan dengan kemungkinan bahwa organisasimampu menyelesaikan sebuah tugas khusus dengan baik jika diminta. Kemangkiran: Frekuensi kejadian-kejadian pekerja bolos dari pekerjaan. Semangat kerja: Kecendrungan anggota organisasi berusaha lebih keras mencapai tujuan san sasaran organisasi termasuk perasaan terikat. Semangat kerja adalah gejala kelompok yang melibatkan kerja sama dan perasaan memiliki. Motivasi: Kecendrungan seseorang individu melibatkan diri dalam kegiatan berarahkan sasaran dalam pekerjaan, ini bukanlah perasaan senang yang relative terhadap hasil berbagai pekerjaan sebagaimana halnya kepuasan, tetapi lebih merupakan perasaan sedia atau rela bekerja untuk mencapai tujuan pekerjaan. Kepuasan kerja:Tingkat kesenangan yang dirasakan seseorang atas peran pekerjannya dam organisasi. Tingkat rasa puas individu bahwa mereka merasa dihargai karena pekerjaan mereka. Beban Pekerjaan: Beban pekerjaan yang diberikan pimpinan kepada bawahan sesuai dengan kemampuan seseorang dan sesuai dengan jumlah kelompok mereka. Waktu Menyelesaikan Tugas: Waktu merupakan salah satu pengukuran efektivitas kerja yang sangat penting sebab dapat dilihat apkah waktu yang digunakan suatu organisasi sudah dijalankan dengan sebaikbaiknya oleh setiap anggota organisasi.

Berdasarkan pedoman pemberian bantu bencana yang di keluarkan oleh Badan Penanggulangan Bencana Nasional bahwa bantuan penampungan/hunian sementara diberikan dalam bentuk tenda-tenda, barak, atau gedung fasilitas umum/sosial, seperti tempat ibadah, gedung olah raga, balai desa, dan sebagainya, yang memungkinkan untuk digunakan sebagai tempat tinggal sementara. Berdasarkan Pedoman Petunjuk Pelaksana penanganan bencana (2015:15) bahwa Standar Minimal Bantuan adalah sebagai berikut; a). Berukuran 3 (tiga) meter persegi per orang. b). Memiliki persyaratan keamanan dan kesehatan. c).Memiliki aksesibititas terhadap fasilitas umum. d). Menjamin privasi antar jenis kelamin dan berbagai kelompok usia.

BPBD juga memberikan Bantuan pangan yang diberikan dalam bentuk bahan makanan, atau masakan yang disediakan oleh dapur umum. Bantuan pangan bagi kelompok rentan diberikan dalam bentuk khusus. Berdasarkan Pedoman Petunjuk Pelaksana penanganan bencana (2015:15) bahwa Standar Minimal Bantuan :a. Bahan makanan berupa beras 400 gram per orang per hari atau bahan makanan pokok lainnya dan bahan lauk pauk. b. Makanan yang disediakan dapur umum berupa makanan siap saji sebanyak 2 kali makan dalam sehari. c. Besarnya bantuan makanan (poin a dan b) setara dengan 2.100 kilo kalori (kcal). Selain itu BPBD juga memberikan Bantuan non pangan yang diberikan kepada korban bencana dalam status pengungsi di tempat hunian sementara pada pasca tanggap darurat, Berdasarkan Pedoman Petunjuk Pelaksana penanganan bencana (2015:15) bahwa dalam bentuk : 1. Peralatan Memasak dan Makan Masing-masing rumah tangga korban bencana dapat memperoleh bantuan peralatan memasak dan perlengkapan untuk makan.

2. Kompor, Bahan Bakar, dan Penerangan Masingmasing rumah tangga korban bencana dapat memperoleh sarana memasak, yaitu kompor dan pasokan bahan bakar dan lampu penerangan secara memadai. 3. Alat-alat dan Perkakas; Korban bencana dapat memperoleh bantuan alat-alat dan perkakas untuk memperbaiki hunian sementara.

Bantuan Sandang terdiri dari :

\section{Perlengkapan Pribadi}

Perlengkapan pribadi merupakan kebutuhan manusia yang sangat penting untuk melindungi diri dari iklim, memelihara kesehatan serta mampu menjaga privasi dan martabat.

\section{Standar Minimal Bantuan :}

a. Memiliki satu perangkat lengkap pakaian dengan ukuran yang tepat sesuai jenis kelamin masing-masing, serta peralatan tidur yang memadai sesuai standar kesehatan dan martabat manusia.b. Perempuan dan anak-anak setidaknya memiliki dua perangkat lengkap pakaian dengan ukuran yang tepat sesuai budaya, iklim, dan musim. . Perempuan dan anak-anak gadis setidaknya memiliki dua perangkat lengkap pakaian dalam dengan ukuran yang tepat sesuai budaya, iklim, dan musim. d. Anak sekolah setidaknya memiliki 2 stel seragam sekolah lengkap dengan ukuran yang tepat sesuai jenis kelamin dan jenjang sekolah yang diikuti.e. Anak sekolah memiliki satu pasang sepatu/alas kaki yang digunakan untuk sekolah. f. Setiap orang memiliki pakaian khusus untuk beribadah sesuai agama dan keyakinannya. g. S e ti a p orang memiliki satu pasang alas kaki. h.

Bayi dan anak-anak dibawah usia 2 tahun harus memiliki selimut dengan ukuran $100 \times 70 \mathrm{~cm}$. 
i. Setiap orang yang terkena bencana harus memiliki alas tidur yang memadai, dan terjaga kesehatannya.j. Setiap kelompok rentan : bayi, anak usia dibawah lima tahun, anak-anak, ibu hamil atau menyusui, penyandang cacat, orang sakit, dan orang lanjut usia, memiliki pakaian sesuai kebutuhan masing-masing. $\mathrm{k}$.

Setiap kelompok rentan, memiliki alat bantu sesuai kebutuhan, misalnya: tongkat untuk lansia dan penyandang cacat. 2 . Kebersihan Pribadi. Tiap rumah tangga memperoleh kemudahan mendapatkan bantuan sabun mandi dan barang-barang lainnya untuk menjaga kebersihan, kesehatan, serta martabat manusia.

\section{Bantuan Sanitasi}

Diberikan dalam bentuk pelayanan kebersihan dan kesehatan lingkungan yang berkaitan dengan saluran air (drainase), pengelolaan limbah cair dan limbah padat, pengendalian vektor, serta pembuangan tinja.

Bantuan Pelayanan Kesehatan yakni Korban bencana, baik secara individu maupun berkelompok, terutama untuk kelompok rentan, dapat memperoleh bantuan pelayanan kesehatan. Bantuan pelayanan kesehatan diberikan dalam bentuk:

1. Pelayanan kesehatan umum meliputi :

a. Pelayanan kesehatan dasar.

b. Pelayanan kesehatan klinis.

2. Pengendalian penyakit menular meliputi :

a. Pencegahan Umum

b. Pencegahan Campak

c. Diagnosis dan Pengelolaan Kasus

d. Kesiapsiagaan Kejadian Luar Biasa

e. Deteksi KLB, Penyelidikan \& Tanggap

f. HIV/AIDS.

3. Pengendalian penyakit tidak menular, meliputi

a. Cedera

b. Kesehatan Reproduksi

c. Aspek Kejiwaan dan Sosial Kesehatan

d. Penyakit Kronis

Pengertian Efektivitas adalah suatu kosa

kata dalam Bahasa Indonesia yang berasal dari bahasa inggris yaitu: "Efective" yang berarti berhasil ditaati, mengesahkan, mujarab dan mujur. Dari sederetan arti di atas, maka yang paling tepat adalah berhasil dengan baik. Jika seseorang dapat bekerja dengan baik maka ia dapat dikatakan bekerja dengan efektif. Dalam pelaksanaan kerja selalu memakai 5 sumber usaha yaitu Pikiran, Tenaga, Waktu, Uang, dan Benda. Walaupun gabungan yang berbeda untuk masing-masing jenis pekerjaan pada umumnya orang melakukan kegiatan tertentu ingin memeperoleh hasil yang maksimal. Tetapi permasalahan efektivitas itu menyangkut banyak hal, oleh karena itu para ahli memberikan defenisi yang beragam untuk menjelaskan apa arti batasan dari pengertian efektivitas itu.

Berdasarkan beberapa pengertian di atas dapat disimpulkan efektivitas merupakan suatu keadaan yang menunjukkan keberhasilan kerja yang ditetapkan. Efektivitas kerja adalah penyelesaian pekerjaan tepat pada waktu yang telah ditentukan, artinya pelaksanaan suatu tugas ditandai baik atau tidak, sangat tergantung pada penyelesaian tugas tersebut bagaimana cara melaksanakannya, dan berapa biaya yang dikeluarkan untuk itu. Hal ini lebih menekankan pada penyelesaian tugas yang telah ditentukan sebelumnya. Berdasarkan pendapat yang dikemukakan ahli di atas maka dapat disimpulkan bahwa efektivitas kerja berhubungan dengan hasil yang telah ditentukan sebelumnya. Satu hal yang perlu digarisbawahi efektivitas kerja tidak dapat dipisahkan dengan efisiensi kerja. Efesiensi kerja berhubungan dengan biaya, tenaga, mutu dan pemikiran. Jadi efektivitas kerja adalah kemampuan untuk memilih tujuan yang tepat dalam mencapai suatu tujuan tertentu atau efektivitas kerja dapat juga diartikan dengan hasil guna penekannya pada efeknya, atau hasil tanpa kurang memperdulikan pengorbanan yang perlu diberikan oleh hasil tersebut.

Jadi efektivitas kerja dalam organisasi merupakan usaha untuk mencapai prestasi yang maksimal dengan menggunakan sumber daya yang tersedia dalam waktu yang relative singkat tanpa menunggu keseimbangan tujuan alat dan tenaga serta waktu. Apa yang dimaksud dengan efektivitas kerja dipertegas Siagian (1996:19) yaitu" Penyelesaian pekerjaan tepat pada waktu yang ditentukan, artinya apabila pelaksanaan tugas dinilai baik atau tidak adalah sangat tergantung pada bilamana tugas tersebut diselesaikan dan bukan terutama menjawab tentang bagaimana melaksanakan serta berapa biaya yang dikeluarkan untuk pekerjaan tersebut".

Dari defenisi di atas dapatlah kiranya diinterpretasikan bahwa efektivitas kerja mengandung arti tentang penekanan pada segi waktu yang dibutuhkan untuk menyelesaikan suatu pekerjaan, dimana semakin cepat pekerjaan itu terselesaikan dengan baik sesuai dengan ketentuan 
yang ditetapkan, maka akan semakin baik pula efektivitas kerja yang dicapai. Demikian pula sebaliknya dengan semakin lamanya pekerjaan tersebut terselesaikan, maka semakin jauh pula pekerjaan tersebut dari keefektifannya. Menurut Handoko, (1999:62) pegawai mampu mencapai efektivitas kerja apabila pegawai "Menunjukkan kemampuan mengakumulasikan pemilihan tujuan yang dilaksanakan dengan peralatan yang akan dipergunakan untuk melaksanakan tujuan tersebut sehingga pekerjaan tersebut terselenggara sebagaimana yang diharapakan".

Pada dasarnya efektivitas kerja dimaksudkan untuk mengukur hasil pekerjaan yang dicapai sesuai dengan rencana, sesuai dengan kebijaksanaan atau dengan kata lain mencapai tujuan, maka hal itu dikatakan efektif. Nilai efektivitas pada dasarnya ditentukan oleh tercapainya tujuan organisasi serta factor kesesuian dalam melaksanakan tugas atau pekerjaannya. Jadi efektivitas kerja pada tiap-tiap organisasi akan berbeda- beda antara organisasi yang satu dengan organisasi yang lainnya, tergantung pada jenis dan sifat dari organisasi yang bersangkutan.

Kerja merupakan suatu symbol yang tidak pernah mati dari pribadi seseorang maupun lingkungan organisasi, sehingga dalam perumusan efektivitas kerja pun perlu ditelaah pula pengertian kerja itu sendiri. Setiap pekerjaan dari tiap individu pegawai dalam organisasi akan ikut menentukan bagi tercapainya hasil kegiatan organisasi yang telah direncanakan terlebih dahulu. Oleh karena itu factor efektivitas kerja banyak dipengaruhi oleh kemampuan orang-orang atau organisasi dalam mencapai tujuannya.

Keberhasilan organisasi dalam mencapai tujuannya tidak dapat melepaskan diri dari perlunya pembagian kerja yang tepat supaya setiap pegawai bisa melaksanakan tugas-tugasnya secara efektif. Pengukuran efektivitas kerja yang penulis lakukan didasarkan atas banyaknya tugas yang dipikul dan jumlah pegawai yang melaksanakan tugas tersebut, sehingga dari kedua hal tersebut dapt disusun sesuai dengan kebutuhan perusahaan/organisasi sehingga menghasilkan efektivitas kerja sebagaimana diharapkan.

Pengukuran efektivitas berdasarkan banyaknya tugas yang dipikul dan jumlah pegawai yang melaksanakan tugas tersebut dapat berarti bahwa bila tugas yang dibebankan kepada pegawai sedikit, sementara jumlah pegawai yang melaksanakan tugas tersebut lebih banyak maka akan terjadi banyak pegawai yang menganggur sehingga menjadi tidak efektif.Sebaliknya jika tugas yang dibebankan banyak sedangkan pegawai yang melaksanakannya terbatas akan terjadi penumpukan pekerjaan yang hal ini akan mengakibatkan banyaknya pekerjaan yang tidak dapat diselesaikan atau tertunda sehingga terjadi ketidakefektifan.

\section{Metode Penelitian}

Penelitian ini jenisnya penelitian deskriptif, yakni penelitian yang dimaksudkan untuk membuat gambaran atau menggambarkan keadaan ataupun kejadian. Penelitian deskriptif menurut Nawawi (1993:63) adalah dapat diartikan "sebagai prosedur pemecahan masalah yang diselidik dengan menggambarkan / melukiskan keadaan subyek / obyek penelitian (seseorang, lembaga, masyarakat dan lain-lain) pada saat sekarang berdasarkan faktafakta yang tampak atau sebagaimana adanya".

Subjek penelitian merupakan sesuatu yang akan diteliti, menurut Faisal (2005:109) "subjek penelitian adalah menunjuk pada orang/individu atau kelompok yang dijadikan unit atau satuan (Kasus) yang diteliti, baik yang menyangkut manusia, atau benda-benda maupun lainnya yang terdapat dalam suatu penelitian. Adapun subjek penelitian ini yakni sebagai berikut: (a) Kepala Badan Penanggulangan Bencana Daerah karena dianggap mengetahui kebijakan tentang penanggulangan Bencana. (b) Kepala Bidang Kedaruratan dan Logistik Badan Penanggulangan Bencana Daerah di anggap mengetahui memahami pelaksanaan kebijakan tentang penanggulangan bencana. (c) Kepala Seksi Logistik Penanggulangan Bencana Badan Penanggulangan Bencana Daerah yang di anggap mengetahui memahami pelaksanaan kebijakan tentang penanggulangan bencana. (d) TIM dari Badan Penanggulangan Bencana Daerah dianggap mengetahui pelaksanaan penanggulangan Bencana , (e) Unsur Masyarakat yang terkena penerima bantuan logistik dari BPBD.

Pengumpulan datadalam penelitian menggunakan tehnik sebagai berikut: (1) Pengamatan/Observasi: yaitu mengadakan pengamatan secara langsung pada objek-objek dan mencatat hal-hal yang berkaitan dengan masalah. (2) Wawancara/interview adalah wawancara subjek penelitian yang berhubungan dengan permasalahan yang menjadi objek dalam penelitian ini. (3) Studi Dokumentasi, yaitu mempelajari dan menggali data sekunder yang diperlukan dalam menunjang penelitian ini

Penelitian ini peneliti menggunakan alatalat pengumpulan data sebagai berikut: (1) Pedoman Wawancara yaitu berupa daftar pertanyaan yang disusun secara sistematis untuk memperoleh informasi, dalam hal ini peneliti mengajukan pertanyaan secara langsung yang berhubungan dengan Implementasi Program Penyaluran Bantuan Bencana. (2) Panduan 
Observasi yaitu peneliti melakukan pengamatan dengan cermat terhadap aspek-aspek yang berhubungan dengan penelitian. (3) Untuk memperoleh dokumentasi digunakan alat bantu fotocopi, Smartphone,

Teknik analisis yang digunakan dalam penelitian ini adalah analisis kualitatif. Miles dan Huberman (1992:20) dalam analisis kualitatif, data yang muncul berwujud kata-kata dan bukan rangkaian angka. Data itu mungkin telah dimunculkan dalam aneka macam cara (observasi, wawancara, intisari dokumen, rekaman) dan yang biasanya diproses sebelum siap digunakan (melalui pencatatan, pengetikan, penyuntingan atau alih tulis), tetapi analisis kualitatif tetap menggunakan kata-kata, yang biasanya disusun ke dalam teks yang diperluas.

Analisis data kualitatif terdiri dari tiga alur kegiatan yang terjadi secara bersamaan yaitu: reduksi data, penyajian data dan penarikan kesimpulan/ verifikasi. Teknik analisis juga mendasarkan pada ketiga alur kegiatan analisis tersebut, yang pada dasarnya dapat terjadi pada waktu yang bersamaan. Jadi pada saat melakukan reduksi data boleh jadi pada saat itu sekaligus dilakukan pembuatan format penyajian data yang memungkinkan untuk penarikan kesimpulan.

\section{Hasil Penelitian Dan Pembahasan}

Kabupaten Sintang memiliki luas wilayah $21.635 \mathrm{Km}^{2}$. Dari luas tersebut, sebagian besar merupakan wilayah perbukitan dengan luas sekitar $13.574 \mathrm{Km}^{2}$ atau 62,74 \% Kabupaten Sintang merupakan terbesar ketiga di Propinsi Kalimantan Barat setelah Kabupaten Ketapang dan Kapuas Hulu. Secara adminitrastif wilayah Kabupaten Sintang berbatasan dengan, Sebelah selatan berbatasan dengan Kabupaten Melawi dan Provinsi Kalimantan Tengah; Sebelah utara berbatasan dengan Kabupaten Kapuas Hulu dan Serawak, Malaysia Timur;Sebelah barat berbatasan dengan Kabupaten Sanggau dan Kabupaten Sekada; Sebelah timur berbatasan dengan Provinsi Kalimantan Tengah.

Daerah Pemerintahan Kabupaten Sintang Pada Tahun 2014 terbagi menjadi 14 Kecamatan, 16 Kelurahan dan 389 desa, kecamatan terluas adalah Kecamatan Ambalau dengan luas $6.386,40 \mathrm{Km}^{2}$ atau 29,52\% dari luas Wilayah Kabupaten Sintang. Sedangkan luas masing-masing kecamatan hanya berkisar 1-29\% dari luas Kabupaten Sintang.Kedudukan Badan Penanggulangan Bencana Daerah Kabupaten Sintang dibentuk dibentuk berdasarkan Peraturan Daerah Kabupaten Sintang Nomor 1 Tahun 2011 Tentang Perubahan Atas Peraturan Daerah Kabupaten Sintang Nomor 21 Tahun 2008 Tentang Pembentuk Organisasi Perangkat Daerah Kabupaten Sintang.

Secara hirarkis Struktur organisasi Badan Penanggulangan Bencana Daerah Kabupaten Sintang Tahun 2017, untuk Lebih Jelas Struktur Organisasi dapat di lihat pada bagan berikut:

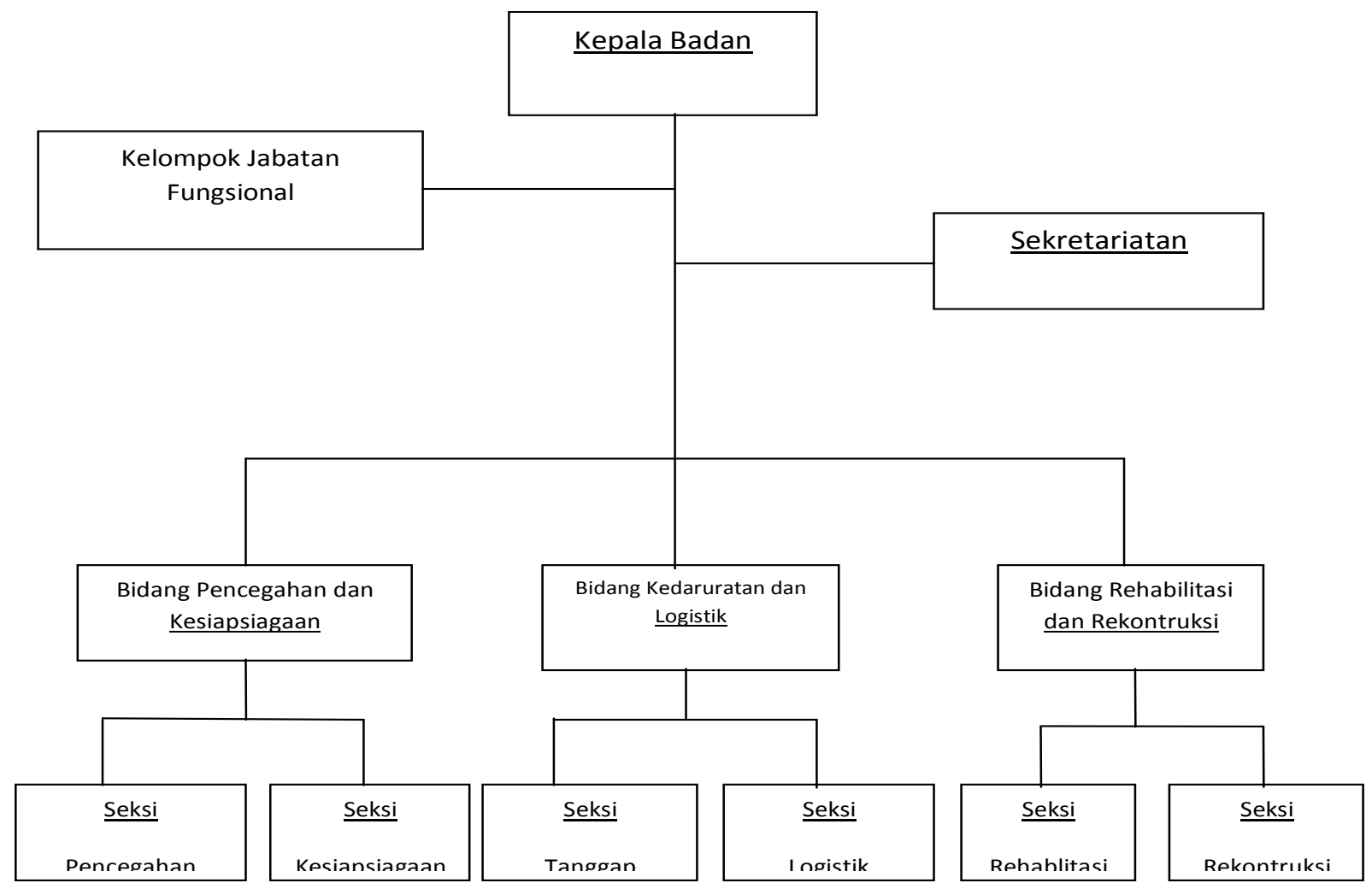

Sumber: Dok. BPBD Kab. Sintang, Januari 2019 
Mekanisme Penyaluran Bantuan untuk korban bencana adalah suatu proses pemberian secara sah dan secara resmi dan biasanya dilakukandi dalam lembaga formal melalui garis perintah atau sifatnya instruktif, berdasarkan struktur organisasi pelaku yang penyaluran bantuan dilakukan/ sebagai petugas organisasi dengan status masing-masing yang tujuannya menyampaikan logistik yang terkait dengan tujuan dan kepentingan lembaga. Suatu koordinasi dapat dilakukan ketika antara dua orang atau lebih untuk penyamaan pandangan tentang yang ada pada suatu organisasi dilakukan berdasarkan prinsip-prinsip hirarkis dan struktur organisasi.

terdapat 8 tahapan proses yang dilakukan hingga bantuantersebut diterima oleh korban bencana banjir. 8 tahapan tersebut sebagai berikut:

1) Kepala desa/Kelurahan melaporkan kejadian bencana banjir atas informasi dari masyarakat kepada Camat setempat. Laporan tersebut selambat-lambatnya 1 jam setelah kejadian tersebut terjadi dan dapat dilakukan melalui telepon yang selanjutnya diikuti laporan tertulis.

2) Berdasar laporan dari kepala desa tersebut, Camat bersama Muspika mengadakan peninjauan lokasi kejadian dan mengambil langkah-langkah seperlunya.

3) Camat melaporkan kronologis kejadian bencana banjir dan langkah-langkah yang telah diambil, serta saran/usulan penanggulangan bencana kepada Bupati. Laporan tersebut dapat dilakukan melalui telepon yang selanjutnya diikuti laporan tertulis dengan tembusan Kepala Pelaksana BPBD.

4) Kepala BPBD menugaskan Tim Reaksi Cepat (TRC) guna mendapatkan data kaji cepat dan langkah-langkah yang perlu diambil.

5) Tim Reaksi Cepat (TRC) dan Camat melaporkan semua permasalahan/keadaan yang terjadi dilapangan kepada Kepala BPBD untuk mendapatkan petunjuk/langkah-langkah strategis selanjutnya.

6) BPBD menindaklanjuti dengan usulan pemberian bantuan/santunan dari Badan Penanggulangan Bencana Daerah melalui Nota Dinas kepada Bupati.

7) Diajukan pencairannya (bantuan/santunan) tersebut kepada Badan Pengelolaan Keuangan dan Kekayaan Daerah (BPKKD).

8) Selanjutnya bantuan tersebut didistribusikan kepada korban bencana banjir.

Dalam penyaluranan sudah dijalankan selama ini cukup baik. Berdasarkan hasil observasi bahwa Kepala Badan Penanggulangan Bencana
Daerah Kabupaten Sintang setiap saat melakukan penyaluran logistik dilakukan koordinasi terlebih dahulu sebagai bentuk kontrol dalam Pelaksanaan tugas pokok dan fungsi. Mereka telah menerima bantuan dari TIM yang melakukan tugas penanganan banjir. Serta juga masyarakat juga merasa terbantu dengan kerja TIM dalam mengevakuasi keluarga mereka.

Proses yang dilakukan antara SOP dengan keadaan di lapangan menunjukkan bahwa pelaporan dilakukan dengan menggunakan telepon dan selanjutnya akan diikuti laporan secara resmi, sedangkan pendistribusian bantuan dari BPBD diberikan kepada Kepala Desa yang diketahui oleh Camat setempat dan selanjutnya barang tersebut didistribusikan oleh aparatur desa yang dibantu oleh TIM. Analisis peneliti bahwa mekanisme penyaluran bantuan harus berdasarkan permintaan asulan dari wilayah yang terdampat bencana alam yankni dari pihak pemerintah desa yakni RT/RW Kepala Dusun, Kepala Desa kepada Pihak Pihak Kecamatan dan selnjutnya pihak Kecamatan mengusul kepada Bupati. Berdasarkan surat tersebut Bupati membuat keputusan melalui Badan Penanggulanganan Bencana Daerah untuk membentuk Tim agar bentuan dapat di salurkan kepada masyakat kurban bencana.

Bentuk bantuan yang disalurkan adalah berupa kebutuhan darurat bagi korban berupa kebutuhan makanan,tempat berteduh yakni dalam bentuk tenda darurat, lahan maupun gedung kosong. Korban banjir dari kalangan perempuan dan anakanak diungsikan ke tempat tinggal sementara yang layak, dibuat suatu mess atau penampungan khusus. Sementara, para kepala rumah tangga ditempatkan di pengungsian dekat tempat asalnya jika hendak menjaga aset di lokasi yang terdampak banjir.

Selanjutnya Ketua Tim Penanggulangan Bencana mengungkapkan bahwa secara umum bentuk bantuan yang disalurkan yakni dalam bentuk paket kebutuhan kebutuhan pokok yaknimakanan dan minuman karena daya tahan tubuh bisa menurun saat kedinginan dan kelaparan. Makanan dan minuman instan yang disiapkan secara cepat yaitu roti, mie, roti, biskuit, dan lainnya.Kemungkinan para korban tidak punya akses untuk memasak. Bisa memberikan bahanbahan mentah, jika terdapat posko pengungsian dengan tim yang siap membuat masakan untuk para korban. Air bersih, khususnya untuk minum, menjaga tubuh pengungsi terhidrasi sehingga tetap fit. Air bersih juga dibutuhkan untuk fasilitas mandi, cuci, kakus (MCK). 
Kebutuhan pokok selanjutnya adalah pakaian. Para pengunsi membutuhkan pakaian, tidak harus mahal tapi layak pakai. Kebutuhan sandang termasuk selimut. Banyak korban di pengungsian jatuh sakit karena tidak kuat hawa dingin akibat hujan, terutama bayi dan manula. Selimut menjadi benda berharga ketika para pengungsi beristirahat, yang mungkin hanya beralaskan koran atau terpal yang tipis.

Berdasarkan hasil wawancara dengan Kepala Badan Penganggulangan Bencana bahwa bentuk bantuan yang tidak kalah penting dalam penangggulangan bencana adalah bantuan Tim Medis dan obat-obatan, yang juga sangatdibutuhkan untuk menghindari datangnya ancaman penyakit yang biasanya muncul kemudian, karena itu bantuan obat diperlukan. Tim medis akan membantu korban yang butuh bantuan segera bermodalkan keterampilan yang telah dikuasai. Kondisi kesehatan lingkungan di tempat pengungsian kadang tidak terjaga baik sehingga perlu ditanggulangi agar tidak menjadi sarana penyebaran penyakit.Selanjutnya, para pengungsi membutuhkan bantuan obat-obatan, seperti minyak kayu putih, tolak angin, vitamin, obat batuk, parasetamol, dan sebagainya. Diperlukan juga perban dan antiseptik untuk luka terbuka.

Beberapa peralatan darurat dibutuhkan korban bencana banjir, seperti peralatan masak, genset listrik, lampu darurat, pompa air darurat, dan sebagainya.Bimbingan konseling dan rohani sangat diperlukan karena Bencana bisa menyebabkan orang stres juga bosan. Anak-anak perlu mendapatkan hiburan dengan permainanpermainan yang melibatkan kelompok hingga mereka lupa dengan suasana yang dihadapi. Bimbingan rohani pun diperlukan untuk membantu mendorong semangat para korban. Bantuan yang mereka terima sangat berharga sehingga dalam keadaan daerah mereka tetap memiliki semangat dalam hidup walupun secara mental dan spritual harus terus mendapat dukungan dari masyarakat lainnya. Dalam kondisi apa pun, maksud pengelolaan logistik adalah untuk mencapai sasaran pelayanan yang efektif, dengan pengeluaran sumber daya yang efisien. Maka setiap langkah kegiatan logistik harus terkendali secara ketat, lebih-lebih untuk menghadapi kondisi bencana, dengan sendirinya taktik dan strategi pelayanan dihadapkan pada kondisi kritis. Oleh karena itu, segala daya dan upaya harus difokuskan pada terciptanya pelayanan yang kritis pula.

Pendistrubusian logistik bantuan bencana, Badan Penanggulangan Bencana Daerah
Kabupaten Sintang harus mampu mengantisipasi berbagai dinamika yang terjadi di lokasi bencana dan harus memerhatikan misi utama dari sistem logistik. Yaitu harus mampu menjamin kesesuaian barang dengan kebutuhan korban secara tepat, barang tersebut harus tersedia pada jumlah yang tepat, barang tersebut harus pada kondisi yang tepat (baik), barang harus dikirim pada lokasi yang tepat, barang-barang harus datang di lokasi pada saat yang tepat, barang harus dapat diterima oleh para korban yang tepat, dan semua kegiatan logistik harus disertai dengan ongkos yang tepat (wajar) agar konsistensi pasok dapat terjamin.

Selanjutnya untuk mengetahui apakah sistem logistik telah berjalan dengan baik, maka harus ditetapkan terlebih dahulu standar kinerja, selanjutnya dilakukan pengukuran, agar dapat dilakukan perbandingan antara kinerja yang dihasilkan dengan standar kinerja yang ditetapkan. Untuk mewujudkan tujuan tersebut, maka dipandang perlu adanya proses audit untuk semua elemen kegiatan logistik bantuan.

Sehubungan bantuan bencana sebagai tanggap sosisal, maka kegiatan logistik akan terus beroperasi. Agar pelaksanaan kegiatan logistik senantiasa konsisten dengan misi, maka diperlukan pengawasan yang ketat dan jika terpaksa terdapat deviasi, secepatnya dilakukan tindakan korektif, dengan demikian misi logistik bantuan bencana dapat terjaga secara konsisten. Pengawasan pendistribusian logistik bertujuan untuk melakukan pemantauan dan pembetulan agar kegiatan logistik bantuan bencana sesuai dengan sasaran.

Padahal proses Efektivitas penyaluran sistem pendistribusian logistik bantuan bencana harus dilakukan secara kontinu dan real time, agar dapat terhindar dari praktik penyelewengan. sehingga dapat dijamin bahwa komoditas bantuan bencana pasti akan sampai dan diterima para korban, dapat diterima secara tepat jumlah, tepat waktu, tepat mutu, tepat sasaran dan tepat lokasi.

Efektivitas penyaluran logistik merupakan salah satu subsistem kendali logistik. Proses pengawasan dilakukan secara periodik, terhadap organisasai pengelola bantuan bencana, sehingga diperoleh sebuah ukuran akuntabilitas yang objektif yang meliputi kesesuaian komoditas, jumlah, mutu, lokasi, waktu, sasaran, dan ongkos.

Dalam pengawasan harus memperhatikana hal-hal sebagai berikut yakni (1) melakukan audit tentang kecocokan antara barangbarang yang diminta dengan yang dikirim. Hal ini 
untuk menilai apakah barang-barang yang dikirim sesuai dengan kebutuhan para korban. Jika sampai terjadi kesalahan kirim, niscaya akan terjadi kemubaziran. Kemubaziran bisa dihindari jika sistem informasi yang dimiliki cukup andal; (2) melakukan pengawasan terhadap jumlah barangbarang ditampung dari para penyumbang dengan jumlah barang yang dikirim dan yang diterima oleh pihak yang berhak. Jika jumlah yang ditampung lebih banyak dibanding yang disalurkan, berarti terdapat stock yang menganggur atau hilang dan mengapa hal itu bisa terjadi; (3) melakukan pengawasan terhadap makanan, minuman, dan obat-obatan. Komoditas ini harus layak makan, demikian pula pakaian dan kantong mayat harus dalam kondisi layak pakai. Hilangkan alasan karena kondisi darurat, sehingga timbul pembenaran jika mengirim komoditas yang tak layak makan dan pakai pun menjadi sah; (4) mengingat lokasi para korban sangat terpencar dan memiliki medan yang masih sangat sulit dilalui sarana transportasi, apakah komoditas bantuan dapat dijamin sampai di lokasi korban, Hal ini penting untuk dilakukan pengujian, karena bukan mustahil terdapat organisasi pengelola bantuan yang asal kirim; (5) mengingat kondisi para korban sangat kritis, mereka memerlukan pasokan bantuan komoditas secara tepat waktu. Apakah bantuan tersebut dikirim kepada para korban tepat saat mereka perlukan? Jika pengiriman tak tepat waktu, berarti mutu pertolongan menjadi rendah. Jika kiriman bantuan bisa datang tepat waktu, diharapkan masih banyak nyawa manusia yang tertolong; (6) bantuan yang berasal dari para penyumbang harus betul-betul sampai kepada para korban yang berhak, jangan sampai diterima oleh pihak-pihak yang tak memiliki hak untuk mendapat bantuan. Hal ini bergantung pada mutu proses pengelolaan bantuan. Maka proses pengawasan harus dilakukan mulai dari proses penerimaan sumbangan, konsolidasi, transportasi, penampungan di lokasi tujuan, dan proses distribusi di lokasi korban; (7) pengawasan semua kegiatan logistik mulai dari proses penerimaan bantuan dari masyarakat, konsolidasi, transportasi, dan distribusi komoditas bantuan bencana dapat dilaksanakan dengan ongkos yang wajar.

Penganganan banjir Tahun 2017 belum dapat ditangani secara maksimal kerena sulitnyan untuk mendapatkan akses titik lokasi banjir dan sulitnya menjangkau desa-desa yang terdampak banjir sehingga, proses evakuasi dan penyaluran logistik untuk kebutuhan korban banjir. Oleh karena itu penanganan secara efektif masih sulit untuk dilakukan.
Penyaluran bantuan untuk korban banjir terkendala lokasi yang sangat jauh dan dalam penyaluran logistik sangat membutuhkan tenaga ekstra untuk menjangkau lokasi. Hal ini karena akses jalan yang sulit di lalui selain dikarenakan kondisi banjir di tambah wilayah desa yang terjampak cukup jauh.

Masyarakat sangat terbantu dengan bantuan yang disalurkan oleh pihak Badan Penganggulangan Bencana Kabupaten Sintang, sehingga kebutuhan anak-anak mereka tidaklah menjadi terlantar, namum demikian masyarakat juga masih berhadap masih perlu penanganan yang lebih cepat. Sehingga penyaluran bantuan kepada masyarakat yang terdampak banjir dapat dilakukan secara efektif.

Analisis peneliti bahwa Jika di kaitkan dengan teori (Robert J. Mokler 2005:139) bahwa efektivitas merupakan membandingkan kegiatan nyata dengan standar yang telah ditetapkan sebelumnya, menentukan dan mengukur penyimpangan-penyimpangan serta mengambil tindakan koreksi yang diperlukan. Sehubungan dengan hasil wawancara di atas bahwa penyaluran bantuan kepada korban banjir yang belum dapat dilakukan secara maksimal hal ini menyebabkan belum efektifnya penyaluran bantuk kepada yang berhak menerima bantuan tersebut.

\section{Penutup}

Mekanisme Penyaluran Bantuan yang dilakukan dapat dikatakan sesuai dengan prosedur yang dilakukan yakni SOP penanganan bencana dengan pengusulan yang dilakukan mulai dari pihak desa kepada camat hingga pemerintahan kabupaten. Bentuk Bantuan yang disalurkan sudah sesuai dengan butuhan masyarakat yang terdampak banjir yakni kebutuhan pokok, obat-obatan dan pembinaan sosial bagi korban. Efektivitas penyaluran bantuan belum dapat dilakukan secara maksimal

\section{Saran}

Mekanisme Penyaluran Bantuan yang telah dilakukan dengan SOP penanganan bencana agar terus dimaksimalkan.Bentuk Bantuan yang sesuai dengan kebutuhan pokok, obat-obatan dan pembinaan sosial bagi korban agar lebih di tingkatkan. Efektivitas penyaluran bantuan yang belum efektif dimasa yang akan datang agar terus dilakukan perbaikan. 
195 Fokus, Volume 17, Nomor 2, September 2019, hlm. 186 - 195

\section{Daftar Pustaka}

Albrow, M. 1996. Birokrasi . Yogjakarta: PT. Tiara Wacana Yogya.

Bagus. 1996. Pelayanan Publik. Yogjakarta: PT. Raja Grafindo Persada.

Dirdjososisworo. 1985. Sosialisasi Dalam Pembangunan. Jakarta: PT. Haji Mas Agung.

Danim, S, 1997, Pengantar Studi Penelitian Kebijakan. Burai Aksara. Jakarta. Effendy, O, 1992, Dinamika Komunikasi. Remaja Rosdakarya. Bandung.

Effendi, U.O. 1984. Sistem Informasi dalam Manajemen. Bandung : Alumni

Faisal, S. 2001. Format-Format-Penelitian Sosial. Jakarta : PT. Raja Grafindo Persada.

Gie, The Liang. 2002. Administrasi Perkantoran Modern. Edisi keempat. Cetakan kedelapan. Yogyakarta: Liberty.

Handoko. T. Hani, 1991. Manajemen Personalia dan Sumber Daya Manusia. Cetakan Pertama. Yogyakarta, Liberti.

Handoko, H. 1995. Manajemen Personalia dan Sumber Daya Manusia. BPFE UGM.Yogjakarta.
Handayaningrat, Soewarno. 2001. Pengantar Studi Administrasi dan Manajemen. Cetakan ke14. CV. Haji Masagung. Jakarta

Islamy, Irfan, M. 2000. Prinsip-prinsip perumusan kebijakan negara. Jakarta : Bumi Aksara

Moenir, AS. 1992. Manajemen Pelayanan Umum di Indonesia, Jakarta : Bumi Aksara.

Ma'moeri, E., 2000. Pengelolaan Informasi dan Teknik Pelaporan. Jakarta: Lembaga Administrasi RI.

Martono. 1991, Komunikasi Publik. Bandung : PT. Remaja Rosdakarya

Nasir, M. 1988. Metode Penelitian, Jakarta: Ghalia.

Nawawi, H. 2003. Metodologi Penelitian, Yogjakarta: Gajah Mada University Press.

Sarwoto 1990, Dasar-Dasar Organisasi dan Manajemen, Jakarta, Ghalia Indonesia.

Siagian Sondang. P, 1991, Organisasi Kepemimpinan dan Perilaku Administrasi, Gunung Agung, Jakarta.

Steers, Richard M, 1998, Efektivitas Organisasi, Terjemahan, Jakarta, PPm, Erlangga.

Sukarna. 1989. Demensi-Demensi Prima Administrasi Negara.Jakarta: Kencana Prenada Media Group 